\title{
Bioconversion of fatty acids at the basis of marine food webs: insights from a compound-specific stable isotope analysis
}

\author{
Marleen De Troch ${ }^{1, *}$, Pascal Boeckx ${ }^{2}$, Clio Cnudde ${ }^{1}$, Dirk Van Gansbeke ${ }^{1}$, \\ Ann Vanreusel ${ }^{1}$, Magda Vincx ${ }^{1}$, Maria José Caramujo ${ }^{3}$ \\ ${ }^{1}$ Marine Biology, Krijgslaan 281/S8, and 2'Laboratory of Applied Physical Chemistry (ISOFYS), Coupure Links 653, \\ Ghent University, Gent 9000, Belgium \\ ${ }^{3}$ Centre of Environmental Biology, Faculty of Sciences, University of Lisbon, Campo Grande C2, Lisbon 1749-016, Portugal
}

\begin{abstract}
Polyunsaturated fatty acids (PUFA) are essential compounds that can limit the productivity of primary consumers in aquatic food webs, where the efficiency in energy transfer at the plant-animal interface has been related to food quality in terms of fatty acids (FA). At this interface, copepods play a pivotal role both as consumers of primary production and as a food source for higher trophic levels. Understanding the role of grazing copepods in the transfer of FA is therefore essential for our knowledge on the overall functioning of marine ecosystems. The harpacticoid copepod Microarthridion littorale grazed for $9 \mathrm{~d}$ on ${ }^{13} \mathrm{C}$ labelled diatoms and bacteria in the laboratory and was then subjected to FA-specific stable isotope analysis. The objective of this analysis was to inspect the copepod's ability to bioconvert short-chain FA (SC-PUFA, $<20$ carbons) into long-chain PUFA (LC-PUFA, $\geq 20$ carbons) and the FA involved in the potential bioconversion pathways. Diatoms and bacteria were chosen as test diets because of their different FA composition, i.e. docosahexaenoic acid (DHA $; 22: 6 \omega 3)$ was absent in the bacteria, and eicosapentaenoic acid (EPA; $20: 5 \omega 3)$ was $<5 \%$ of the total FA weight of bacteria. The presence of labelled DHA in copepods feeding on bacteria showed that this PUFA must have been converted from other FA, possibly EPA. The FA composition of copepods in the laboratory was different from that of field copepods, which suggests the availability of more food sources in the field than those offered in the experiment. The weight proportion of C18 FA decreased in copepods feeding on either bacteria or diatoms relative to field copepods, while the proportion of both EPA and DHA increased. In contrast to planktonic calanoid copepods that have limited ability to bioconvert FA, benthic harpacticoid copepods apparently developed the ability to elongate FA and to exploit niches with poor quality food. Moreover, by improving the quality of the food they graze upon, especially in terms of EPA and DHA, harpacticoid copepods upgrade the nutritive value of food available to the higher trophic levels in marine food webs.
\end{abstract}

KEY WORDS: Fatty acids $\cdot$ Bioconversion $\cdot$ Harpacticoid copepods $\cdot$ Compound-specific stable isotope analysis

\section{INTRODUCTION}

Tracing energy flow in food webs and determining the factors that control food web interactions are key issues in ecology (Matson \& Hunter 1992, Wilbur
1997). The interface between primary and secondary producers at the basis of marine food webs is of particular interest because of the highly variable efficiency of transfer of biomass and energy (Brett \& Goldman 1997, Micheli 1999). Fatty acids (FA) have 
been identified as key factors modulating the efficiency of energy transfer at this plant-animal interface (Müller-Navarra et al. 2004), and it is thus of paramount importance to clarify how consumers assimilate and modify dietary FA.

The concept of FA being transferred conservatively through aquatic food webs and of their use as biomarkers was first suggested in 1935 by Lovern. As a result, FA biomarker analyses have become an important tool for resolving trophic interactions in both marine (Dalsgaard et al. 2003) and freshwater ecosystems (Napolitano 1999). Nevertheless, the perfect trophic marker is defined as a compound whose origin can be uniquely and easily identified, that is inert and nonharmful to organisms, and, most importantly, that is not selectively processed during food uptake and incorporation, and that is metabolically stable and hence transferred from one trophic level to the next in a qualitative and quantitative manner (Dalsgaard et al. 2003). In fact, apart from bacterial FA biomarkers detected in eukaryotic cells (Ederington et al. 1995), the conservative incorporation and turnover of specific FA biomarkers have seldom been documented (see St. John \& Lund 1996, Kirsch et al. 1998 for examples). When using FA as biomarkers, it is therefore of paramount importance to know to what extent they are directly incorporated or transformed after assimilation.

The modification of ingested FA by consumers has important implications for higher trophic levels because the quality of nutrients available for higher trophic levels may be altered and improved. FA with 2 or more double bonds in the aliphatic chain (polyunsaturated FA or PUFA) usually account for at least a third of all FA in organisms in which they play several major roles. Despite their importance, PUFA cannot be formed de novo by animals and must be obtained directly from diet or bioconverted from certain precursor FA (Canuel et al. 1995, Iverson 2009). As in all ecosystems, most PUFA in aquatic food webs originate from the primary producers, essentially from photo-autotrophs (Tocher 2008). According to Brett \& Müller-Navarra (1997), all herbivores convert the short-chain PUFA (SC-PUFA, PUFA with $<20$ car-

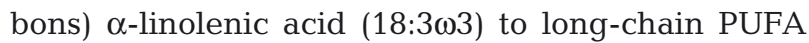
(LC-PUFA, PUFA with $\geq 20$ carbons), such as eicosapentaenoic (EPA, 20:5 03 ) and docosahexaenoic (DHA, 22:6 $\omega 3$ ) acids, albeit with different efficiency. Marine protists, namely thraustochytrids, are also known to accumulate PUFA in lipid droplets (Kobayashi et al. 2011). They are considered an alternative to fish oils as a source of LC-PUFA (Kobayashi et al. 2011) and are established candidates for commercial production of DHA (for review, see Raghukumar 2008). Within the zooplankton, this phenomenon seems to be more important in copepods than in cladocerans (Desvilettes et al. 1997a). Nevertheless, the ability to bioconvert 18:3 $\omega 3$ to EPA and DHA may not be shared by all copepod taxa, as calanoids apparently lack the necessary enzymes to produce significant amounts of PUFA (Sargent \& Henderson 1986, Bell et al. 2007, Bell \& Tocher 2009), while certain harpacticoids (e.g. Tisbe holothuriae) seem to efficiently bioconvert FA to produce high levels of PUFA regardless of their levels in the diet (Norsker \& Støttrup 1994, Nanton \& Castell 1998). Another harpacticoid, Nitokra lacustris, was able to elongate FA chains (dietary linolenic and linoleic acid) obtained from formulated feed (Rhodes \& Boyd 2005).

The existence of bioconversion by (harpacticoid) copepod species has been illustrated by contrasting the FA composition of the food and the grazer, yet the detailed biochemical mechanisms of bioconversion at this trophic level remain undocumented. Prior to the use of FA as dietary tracers in field studies, Kelly \& Scheibling (2012) suggested that controlled feeding experiments are needed to verify the transfer of indicator FA from food to consumer. Data from such experiments could provide evidence of FA biosynthesis and selective retention. Moreover, a better knowledge of the mechanisms and triggers of bioconversion is essential to understand the production of LC-PUFA, the availability of which is likely to be the main constraint for developing sustainable carnivore aquaculture in the coming decades (Olsen 2011).

Combining FA and stable isotope analyses has proven to be a helpful approach to identifing major sources of organic matter which contribute to the diet of marine benthic invertebrates (Kiyashko et al. 1998, Kharlamenko et al. 2001, 2008, El-Sabaawi et al. 2009). This so-called 2-dimensional approach to trophodynamics (Nyssen et al. 2005) is particularly useful in case of small $\delta^{13} \mathrm{C}$ differences between carbon sources. Both techniques are often used complementarily, i.e. they are analysed separately, and the FA profiles and stable isotope signatures are compared.

In the present study, we analysed the ${ }^{13} \mathrm{C}$ composition of individual FA through compound-specific carbon isotope analysis (CSIA) (Pancost \& Pagani 2006, Budge et al. 2008) to trace the incorporation of ${ }^{13} \mathrm{C}$ labelled FA from the diet into the consumer tissues and to unravel bioconversion pathways. We also evaluate the role of the original food source (bacteria vs. diatoms) as a trigger for bioconversion. 
Harpacticoid copepods were used as test organisms because of the limited information available on their trophic interactions with the microbial community, which is in sharp contrast with their well-known important ecological roles (e.g. Hicks \& Coull 1983). Harpacticoids feed on a variety of food items, including diatoms (Decho 1986, Chandler \& Fleeger 1987) and bacteria (Decho \& Fleeger 1988) that have very contrasting lipid contents and profiles. Diatoms produce lipids as their primary storage material, which ascribes them great value as lipid producers, especially of PUFA, in aquatic food webs (Dunstan et al. 1993). In contrast to the high PUFA content of diatoms, bacteria generally have a low PUFA content (Yazawa et al. 1988, Kaneda 1991). Nevertheless, bacteria may be nutritiously suitable for copepods that do not exhibit reduced reproduction when fed diets deficient in EPA and DHA (Ustach 1982, Norsker \& Støttrup 1994). Acting as first consumers of primary production and as a food source for higher trophic levels (e.g. fish), copepods form an important link between autotrophs and heterotrophs at the basis of marine food webs (e.g. Sogard 1984, De Troch et al. 1998, Buffan-Dubau \& Carman 2000). Moreover, in view of their high LC-PUFA content and their ideal size range as food for most marine fish fry, copepods are of particular interest for aquaculture applications (Støttrup 2000, Lee et al. 2005). Additionally, from an ecological point of view, it is of general interest to know the main origin and transfer of LC-PUFA in marine food webs.

\section{MATERIALS AND METHODS}

\section{Culture conditions and labelling technique}

Both food sources (diatoms and bacteria) and grazers (harpacticoid copepods) were collected from sediments at the Paulina silty intertidal flat (SW Netherlands, $\left.51^{\circ} 21^{\prime} \mathrm{N}, 3^{\circ} 43^{\prime} \mathrm{E}\right)$. The dominant harpacticoid copepod Microarthridion littorale (family Tachidiidae) was extracted alive from the sediment using a mixed technique of sediment decantation and extraction via white light attraction. Copepods were washed 3 times over a $38 \mu \mathrm{m}$ sieve and placed in Petri plates with artificial seawater overnight in order to empty their intestines prior to the start of the experiment.

The diatom Navicula phyllepta was isolated from the sediment by means of lens tissue and microscopic cover glasses. Axenic cultures were grown in $f / 2$ medium based on filtered and sterilized artificial sea- water (salinity: 32) (Guillard 1975) with addition of antibiotics (penicillin and streptomycin). The diatoms were labelled with ${ }^{13} \mathrm{C}$ by adding $5 \mathrm{ml}$ of a $\mathrm{NaH}^{13} \mathrm{CO}_{3}$ stock solution $\left(336 \mathrm{mg} \mathrm{NaH}{ }^{13} \mathrm{CO}_{3}\right.$ in $100 \mathrm{ml}$ Milli-Q $\mathrm{H}_{2} \mathrm{O}$ sodium bicarbonate, ${ }^{13} \mathrm{C}, 99 \%$, Cambridge Isotope Laboratories) per $100 \mathrm{ml}$ of culture medium. The cultures were grown in tissue bottles $\left(175 \mathrm{~cm}^{2}\right.$ surface) during $10 \mathrm{~d}$ in a climate room at 16 to $18^{\circ} \mathrm{C}$ with a 12:12 h light:dark period and 25 to $50 \mu \mathrm{mol}$ photons $\mathrm{m}^{-2} \mathrm{~s}^{-1}$. By the time of setting the experiment, the cells were $24.1 \pm 0.9 \mu \mathrm{m}(\mathrm{n}=20)$ in length. The labelling technique resulted in isotope signatures $\left(\delta^{13} \mathrm{C}\right)$ of $-16.4 \%$ and $19516.3 \%$ for untreated and ${ }^{13} \mathrm{C}$ enriched cultures, respectively.

The sediment was shaken by hand and using a vortex mixer to extract bacteria and bring them into suspension. Bacteria were initially grown on marine agar for $4 \mathrm{~d}$ at 15 to $16^{\circ} \mathrm{C}$. To maximise the bacterial diversity, a dilution series was set up in the inoculate. The liquid growth medium consisted of autoclaved artificial seawater (salinity: 24.5, Instant Ocean synthetic salt), beef extract (DIFCO, $3 \mathrm{~g} \mathrm{l}^{-1}$ ) and Bacto Peptone (DIFCO, $5 \mathrm{~g} \mathrm{l}^{-1}$ ). Two Erlenmeyer flasks were inoculated with the bacterial mix scraped from the agar plates and placed on a shaking table at room temperature. After 3 d of growth, new growth medium was prepared as stated above but diluted 20 -fold, and $0.5 \mathrm{~g} \mathrm{l}^{-1}{ }^{13} \mathrm{C}$ glucose (D-glucose, $\mathrm{U}-{ }^{13} \mathrm{C} 6$, $99 \%$, Cambridge Isotope Laboratories) was added to label the bacteria. After $24 \mathrm{~h}$ of growth, this labelling technique yielded an increase in $\delta^{13} \mathrm{C}$ from $-15.2 \%$ to $9092.4 \%$ for untreated and ${ }^{13} \mathrm{C}$ enriched cultures, respectively.

\section{Experimental design}

Prior to the experiment, the labelled culture medium of bacteria and diatoms was gently washed away and replaced by autoclaved artificial seawater (salinity: 32 , without f/2 growth medium) 3 times to minimise any additional growth of diatoms or bacteria during the feeding experiments. Although faecal matter and copepods have associated bacteria (De Troch et al. 2010), we assume that the contribution of this bacterial source is minimal in comparison with the biomass of the experimental food sources.

At the start of the experiment, triplicate samples for the copepod Microarthridion littorale (200 individuals each) from the field were stored at $-80^{\circ} \mathrm{C}$ for analysis of initial FA composition (field conditions). Samples of the bacteria and diatoms were stored at $-20^{\circ} \mathrm{C}$ and $-80^{\circ} \mathrm{C}$ for stable isotope and FA composi- 
tion analyses, respectively, as a control for initial labelling. The experiment was conducted in a climate room at 16 to $18^{\circ} \mathrm{C}$ with a $12: 12 \mathrm{~h}$ light:dark period and 25 to $50 \mu \mathrm{mol}$ photons $\mathrm{m}^{-2} \mathrm{~s}^{-1}$.

The experimental design consisted of 4 treatments with 3 replicates each: (1) Microarthridion littorale $\left({ }^{12} \mathrm{C}\right.$ bacteria): 250 copepods fed with ${ }^{12} \mathrm{C}$ bacteria (2) M. littorale $\left({ }^{13} \mathrm{C}\right.$ bacteria): 250 copepods fed with ${ }^{13} \mathrm{C}$ bacteria (3) M. littorale $\left({ }^{12} \mathrm{C}\right.$ diatoms): 250 copepods fed with ${ }^{12} \mathrm{C}$ diatoms (4) M. littorale $\left({ }^{13} \mathrm{C}\right.$ diatoms): 250 copepods fed with ${ }^{13} \mathrm{C}$ diatoms.

A total of $2 \times 10^{11}$ bacterial cells (Treatments $1 \& 2$ ) or $3 \times 10^{6}$ diatom cells (Treatments $3 \& 4$ ) per experimental unit (Petri plate, $8.4 \mathrm{~cm}$ diameter, $55.4 \mathrm{~cm}^{2}$ surface) were applied by means of a micropipette. It took $\sim 15$ min before all cells had settled to form a homogeneous layer at the bottom of the Petri plate (M. De Troch pers. obs.). Based on our previous experiments (De Troch et al. 2005, 2007), the level of food supply (diatoms) provided can be considered as above the feeding saturation level. At the end of the experiment, there was no food depletion in any of the treatments.

After $9 \mathrm{~d}$, the experiment was terminated by estimating the mortality of copepods in the experimental unit and sorting them for further analysis. From each replicate, 20 copepods were picked at random and stored at $-20^{\circ} \mathrm{C}$ for further total ${ }^{13} \mathrm{C}$ analysis. Within $2 \mathrm{~h}$ after thawing (to avoid label leakage), they were washed 5 times in deionised water and transferred into tin capsules $(8 \times 5 \mathrm{~mm}$, Elemental Microanalysis $)$ using a micro needle. These tin capsules were desiccated at $60^{\circ} \mathrm{C}$ for $12 \mathrm{~h}$.

For CSIA, the remaining live copepods (on average 130 to 220 individuals depending on the survival rate; see 'Results') were picked out and washed 5 times in artificial seawater to remove food particles from the cuticle and left for $4 \mathrm{~h}$ to allow emptying of the gut. Finally, the copepods were placed on a glass fibre filter $(\mathrm{GF} / \mathrm{F})$ with a pipette and were stored at $-80^{\circ} \mathrm{C}$ in an Eppendorf tube until the FA extraction.

\section{Stable isotope and FA analysis}

For each replicate, $\delta^{13} \mathrm{C}$ values and copepod biomass (expressed as total carbon) were measured with a continuous flow isotope ratio mass spectrometer (Europa Integra) at the UC Davis Stable Isotope Facility (University of California, USA).

Hydrolysis of total lipid extracts (in triplicate) of copepods collected in the field and methylation to
FA methyl esters (FAME) was achieved by a modified 1-step derivatisation method after Abdulkadir \& Tsuchiya (2008). The boron trifluoride-methanol reagent was replaced by a $2.5 \% \mathrm{H}_{2} \mathrm{SO}_{4}$-methanol solution, since BF3-methanol can cause artefacts or loss of PUFA (Eder 1995). The FAME thus obtained were analysed using a gas chromatograph (HP $6890 N$ ) with a mass spectrometer (HP 5973). The samples were run in splitless mode at an injector temperature of $250^{\circ} \mathrm{C}$ using an HP88 column (Agilent $\mathrm{J} \& \mathrm{~W}_{;}$Agilent). The oven temperature was programmed at $50^{\circ} \mathrm{C}$ for 2 min, followed by a ramp at $25^{\circ} \mathrm{C} \min ^{-1}$ to $175^{\circ} \mathrm{C}$ and then a final ramp at $2^{\circ} \mathrm{C} \mathrm{min}^{-1}$ to $230^{\circ} \mathrm{C}$ with a 4 min hold. The FAME were identified by comparison with the retention times and mass spectra of authentic standards and mass spectral libraries (WILEY, NITS05) and analysed using the software MSD ChemStation (Agilent Technologies). Quantification of individual FAME was accomplished by the use of external standards (Supelco \#47885, Sigma-Aldrich). The quantification function of each individual FAME was obtained by linear regression of the chromatographic peak areas and corresponding known concentrations of the standards (ranging from 5 to $250 \mu \mathrm{g} \mathrm{ml}^{-1}$ ).

Hydrolysis of total lipids of copepods and methylation to FAME for FA-specific ${ }^{13} \mathrm{C}$ measurement (CSIA) was achieved by a 1-step derivatisation method as described above. The FAME obtained from the triplicate extracts of the copepods in each of the 4 treatments were analysed by capillary gas chromatography combustion-isotope ratio mass spectrometry (GC-C-IRMS) using a Finnigan Trace GC Ultra with combustion interface (GC combustion III) coupled to a Finnigan Deltaplus ${ }^{\mathrm{XP}}$ continuous flow stable isotope ratio mass spectrometer (GC-C/TC DeltaPLUSXP Thermo Scientific). All samples were run in splitless mode and at an injector temperature of $250^{\circ} \mathrm{C}$, using a VF-23ms column $(60 \mathrm{~m} \times 0.32 \mathrm{~mm}$ inner diameter, $\mathrm{df}=0.15$; Varian) with a He flow rate of $1 \mathrm{ml} \mathrm{min}{ }^{-1}$. The oven temperature was programmed at $50^{\circ} \mathrm{C}$ for $2 \mathrm{~min}$, followed by a ramp at $15^{\circ} \mathrm{C} \mathrm{min}^{-1}$ to $100^{\circ} \mathrm{C}$, then a second ramp at $2^{\circ} \mathrm{C} \mathrm{min}^{-1}$ to $220^{\circ} \mathrm{C}$ and a final ramp at $5^{\circ} \mathrm{C} \mathrm{min}^{-1}$ to $230^{\circ} \mathrm{C}$ with a 5 min hold. Each extract was run in duplicate on the GC-C-IRMS ( $5 \mu \mathrm{l}$ injected per run) to ensure reliable mean atom $\%{ }^{13} \mathrm{C}$ values. The average chromatographic peak areas and atom $\%{ }^{13} \mathrm{C}$ values were used in all calculations.

For the CSIA, the FAME were identified as described above for the FA analysis on the GC-MS and analysed using the software Isodat NT 2.0 (Thermo 
Electron). FAME peak areas were validated by determining their ratio relative to that of the universally occurring 16:0, and FAME peaks with a ratio inferior to 0.02 were excluded from the data set (see Drijber et al. 2000). Validation and quantification of peaks was done as described above.

Shorthand FA notations of the form A:B $\omega \mathrm{X}$ were used, where A represents the number of carbon atoms, B gives the number of double bonds, and $\mathrm{X}$ gives the position of the double bond closest to the terminal methyl group (Guckert et al. 1985).

\section{Data analysis}

Total isotope signature of copepods to trace food uptake

The total enrichment of the copepods after $9 \mathrm{~d}$ of feeding is reported as $\delta^{13} \mathrm{C}$ values. These $\delta^{13} \mathrm{C}$ values were further standardised per individual copepod ( $\mu \mathrm{g}{ }^{13} \mathrm{C}$ per copepod) as recommended by Middelburg et al. (2000): incorporation of ${ }^{13} \mathrm{C}$ is reflected as excess (above natural abundance) ${ }^{13} \mathrm{C}$, expressed as total uptake (I) in $\mathrm{mg}{ }^{13} \mathrm{C}$ per individual and calculated as the product of excess ${ }^{13} \mathrm{C}(\mathrm{E})$ and individual biomass (organic carbon). Excess ${ }^{13} \mathrm{C}$ is the difference between the fraction ${ }^{13} \mathrm{C}$ of the control copepods $\left(F_{\text {control, }}\right.$ i.e. based on the natural signature of copepods feeding on unlabelled bacteria or unlabelled diatoms) and the fraction ${ }^{13} \mathrm{C}$ of the treatment copepods $\left(\mathrm{F}_{\text {treatment }}\right.$ i.e. based on the signature of copepods feeding on a labelled diet), where $\mathrm{F}={ }^{13} \mathrm{C} /\left({ }^{13} \mathrm{C}\right.$ $\left.+{ }^{12} \mathrm{C}\right)=\mathrm{R} /(\mathrm{R}+1)$. The carbon isotope ratio $(\mathrm{R})$ was derived from the measured $\delta^{13} \mathrm{C}$ values as $\mathrm{R}=\left[\delta^{13} \mathrm{C} /\right.$ $(1000+1)] \times \mathrm{R}_{\mathrm{VPDB}}$, with $\mathrm{R}_{\mathrm{VPDB}}=0.0112372$ as $\delta^{13} \mathrm{C}$ is expressed relative to Vienna Pee Dee Belemnite (VPDB).

Since the food sources offered (diatoms vs. bacteria) had different initial $\Delta \delta^{13} \mathrm{C}$ signatures (9107.5\% for bacteria vs. $19532.6 \%$ for diatoms), the uptake of dietary carbon per individual was further standardised, taking into account the proportion of ${ }^{13} \mathrm{C}$ in each food source. The amount of total carbon that was taken up by copepods and expressed per individual copepod in the treatments was multiplied with the factors 11.23 and 5.67 for the treatments with labelled bacteria and diatoms, respectively. These correction factors were derived from the excess heavy isotope $\left({ }^{13} \mathrm{C}\right)$ percentage of total carbon atoms (atom percentage ${ }^{13} \mathrm{C}$ ) in each food sources, i.e. on average $9.07 \%{ }^{13} \mathrm{C}$ for bacteria and $17.63 \%{ }^{13} \mathrm{C}$ for diatoms.

\section{FA-specific stable isotope analysis}

The carbon mass of each individual FA in a single copepod was derived from the number of moles of the FA in the copepods. The molecular weight of each labelled FA was calibrated by its carbon atom percentage to incorporate the carbon weight variation according to the ${ }^{13} \mathrm{C}:{ }^{12} \mathrm{C}$ ratio, e.g. DHA methyl ester molecular weight equals 342.5204 when all $\mathrm{C}=12.011$, while DHA methyl ester molecular weight equals 344.8204 when the atom ${ }^{13} \mathrm{C}$ percentage $=10 \%$ (i.e. $10 \%$ of all carbon with molecular weight of 13.011).

Isotopic ratios are normally expressed in $\delta$ notation according to the calculations shown above for total isotope signature. In the present study, the enrichment in ${ }^{13} \mathrm{C}$ of the copepod FA after $9 \mathrm{~d}$ of feeding on the ${ }^{13} \mathrm{C}$ enriched diets is reported as excess isotope ${ }^{13} \mathrm{C}$ percentage (atom $\%{ }^{13} \mathrm{C}$ ), which is more appropriate for labelled samples (Graeve et al. 2005). The incorporation of ${ }^{13} \mathrm{C}$ into each FA was expressed as I in $n g{ }^{13} \mathrm{C}$ per individual and calculated as the product of $\mathrm{E}$ and FA carbon mass, as described above for total carbon enrichment. The amount of dietary carbon assimilated by copepods into each FA was estimated based on the ${ }^{13} \mathrm{C}$ uptake, multiplied by the factor derived from the percentage of ${ }^{13} \mathrm{C}$ in each $\mathrm{FA}$ in the food source, as in the following equation:

$$
\begin{aligned}
& \mathrm{C}_{\text {ass }}\left(\mathrm{ng} \mathrm{CFA} \text { ind } .^{-1}\right)=\mathrm{ng}{ }^{13} \mathrm{C} \mathrm{FA}^{-1} \text { ind }^{-1} \times \\
& 100 / \text { atom } \%{ }^{13} \mathrm{C} \text { corresponding dietary FA }
\end{aligned}
$$

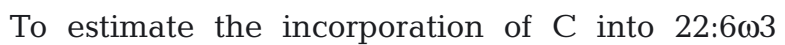

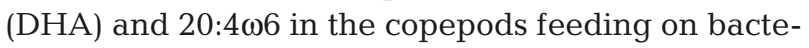
ria (where none of these FA were recorded), we used

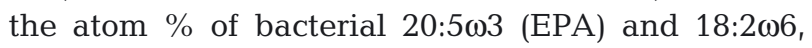
respectively.

To calculate the amount (mass) of each dietary FA assimilated by the copepod, we multiplied the number of moles of FA assimilated by the corresponding FA molecular weight:

$\mathrm{FA}_{\text {ass }}\left(\right.$ ng FA ind $\left.{ }^{-1}\right)=$ number of assimilated moles of FA $\times$ molecular weight of dietary FA, and the number of assimilated moles was calculated as follows:

$$
\begin{aligned}
& \text { Moles FA ind } .^{-1}= \\
& \frac{\mathrm{C}_{\text {ass }}\left(\mathrm{ng} \mathrm{C} \mathrm{FA} \mathrm{ind} .^{-1}\right)}{\mathrm{C}_{\text {food }} \text { (carbon weight of } 1 \text { mole of dietary }} \\
& \text { FA at corresponding atom } \left.\%{ }^{13} \mathrm{C}\right)
\end{aligned}
$$

$\mathrm{FA}_{\text {ass }}\left(\right.$ ng FA ind.$\left.^{-1}\right)=\mathrm{C}_{\text {ass }}\left(\right.$ ng C FA ind.$\left.^{-1}\right) / \mathrm{C}_{\text {food }}$ (carbon weight of one mole of dietary FA at corresponding atom $\%{ }^{13} \mathrm{C}$ ) $\times$ molecular weight of dietary FA 
Differences in uptake among treatments were tested by means of 2-way analyses of variance with Statistica 7.0 software (StatSoft 2004). A posteriori comparisons were carried out with the Tukey HSD test using $95 \%$ confidence limits. Prior to the analyses of variance, the Cochran's C-test was used to check the assumption of homoscedasticity.

Multivariate analysis of FA compositions was conducted with a non-metric multidimensional scaling method based on Bray-Curtis similarity using Primer 6 software (Clarke \& Gorley 2006). Subsequently, a 1-way analysis of similarities (ANOSIM) was used to test for significant differences between the groups based on their origin (i.e. field, copepods feeding on bacteria, copepods feeding on diatoms and the 2 food sources separately). Finally, percentages of similarity (SIMPER) were calculated with untransformed, absolute data to determine the main FA contributing to any differences.

\section{RESULTS}

\section{Food uptake by copepods: total ${ }^{13} \mathrm{C}$ enrichment}

Microarthridion littorale feeding on a bacterial diet (Treatments $1 \& 2$ ) had an average survival rate of $55 \%$ at the end of the $9 \mathrm{~d}$ experiment. This low survival rate contrasts with the copepods feeding on diatoms (Treatments $3 \& 4$ ) that exhibited a survival rate of $98 \%$ after $9 \mathrm{~d}$ of grazing. As a consequence of this difference in survival rates, the average number of copepods available for FA stable isotope analysis was restricted to 130 and 220 ind. for the treatments with bacteria and diatoms, respectively. The minimum required number of individuals for total stable isotope analysis was kept constant (20 ind.).

Total ${ }^{13} \mathrm{C}$ enrichment of Microarthridion littorale was clearly higher after grazing on diatoms (average $\Delta \delta^{13} \mathrm{C}=3541 \pm 412 \%$ ) than after grazing on bacteria (average $\Delta \delta^{13} \mathrm{C}=62 \pm 8 \%$ ). The I of labelled diatom carbon per individual copepod (Treatment 4 ; individual uptake $=141 \pm 23 \mathrm{ng}$ C) was significantly higher than the uptake of bacteria (Treatment 2; individual uptake $=3.6 \pm 0.4 \mathrm{ng} C)\left(\mathrm{F}_{1,2}=37.22, \mathrm{p}<0.01\right)$.

The total uptake of bacterial carbon during the feeding experiment was insufficient to compensate for the metabolic costs of living during $9 \mathrm{~d}$, and the weight of copepods feeding on bacteria decreased

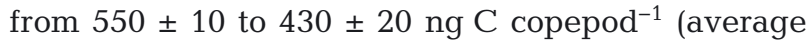
loss of $21.7 \%$ ). When feeding on diatoms, copepods increased their total carbon weight from $550 \pm 10$ to $650 \pm 30$ ng C copepod ${ }^{-1}$ (average increase of $19.3 \%$ ).

\section{FA composition of the food}

The most abundant FA in both diatoms and bacteria used as food for copepods were 16:0 and 16:107 (Fig. 1A,B). The major PUFA present in diatoms were EPA and DHA (Fig. 1b), while in bacteria, DHA was absent (Fig. 1a). In bacteria, PUFA were present in small amounts and were represented by EPA, which ranged from 0.4 to $1.7 \%$ of total FA, and traces of $18: 2 \omega 6(<0.1 \%$ of total FA).

Both food sources (bacteria and diatoms) incorporated the added ${ }^{13} \mathrm{C}$ label differently into their FA (FA profiles of the food, back rows in Fig. $1 \mathrm{C}, \mathrm{D})$. The ${ }^{13} \mathrm{C}$ enrichment of FA was generally higher for diatoms than for bacteria, although the enrichments of the most abundant FA (16:0 and 16:107) were similar in both diets (Fig. 1C,D). Bacteria mainly assimilated the ${ }^{13} \mathrm{C}$ into short-chain FA, monounsaturated FA and SC-PUFA with a maximum enrichment of $24.3 \mathrm{~atm} \%$ ${ }^{13} \mathrm{C}$ in 18:167c (Fig. 1C), while diatoms incorporated a larger amount of ${ }^{13} \mathrm{C}$ into LC-PUFA (30.7 atm \% ${ }^{13} \mathrm{C}$ for EPA) than into the shorter chain FA (8.5 to $\left.19.5 \mathrm{~atm} \%{ }^{13} \mathrm{C}\right)$. PUFA were clearly more ${ }^{13} \mathrm{C}$ enriched in diatoms than bacteria, with the exception of

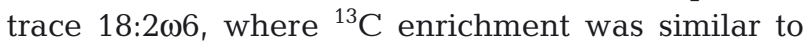
that of diatoms $\left(\sim 12.58\right.$ atom $\left.\%{ }^{13} \mathrm{C}\right)$.

\section{Effect of a monotonous diet on the grazer's FA composition}

The total FA content of Microarthridion littorale feeding on a monotonous diet of bacteria for $9 \mathrm{~d}$, significantly decreased from $264.3 \pm 1.6 \mathrm{ng}$ copepod $^{-1}$ at the start of the feeding experiment (i.e. animals collected in the field) to $137.4 \pm 3.9 \mathrm{ng} \operatorname{copepod}^{-1}$ at the end of the feeding experiment $\left(F_{1,2}=13.72, \mathrm{p}<0.01\right.$; Tukey HSD post-hoc: $\mathrm{p}<0.05)$. Total copepod FA content after feeding on the diatom diet for $9 \mathrm{~d}$ $\left(261.2 \pm 51.5 \mathrm{ng}\right.$ copepod $\left.^{-1}\right)$ was not significantly lower than the FA content of copepods at the start of the experiment $\left(264.3 \pm 1.6 \mathrm{ng}\right.$ copepod $^{-1}$, Tukey HSD post-hoc: $\mathrm{p}=0.99$ ).

Both experimental diets changed both the absolute and relative FA composition of copepods (Figs. 1 \& 2). After feeding on both bacteria and diatoms, the FA profiles of Microarthridion littorale more closely resembled the FA profiles of the food sources and deviated further from their original field composition (Fig. 3). Copepods had a general absolute decrease in C18 FA (both treatments) and an absolute increase in C16 FA (diatom treatment). In the treatment with bacteria, the relative FA contribution of 16:0 (Fig. 1A) 

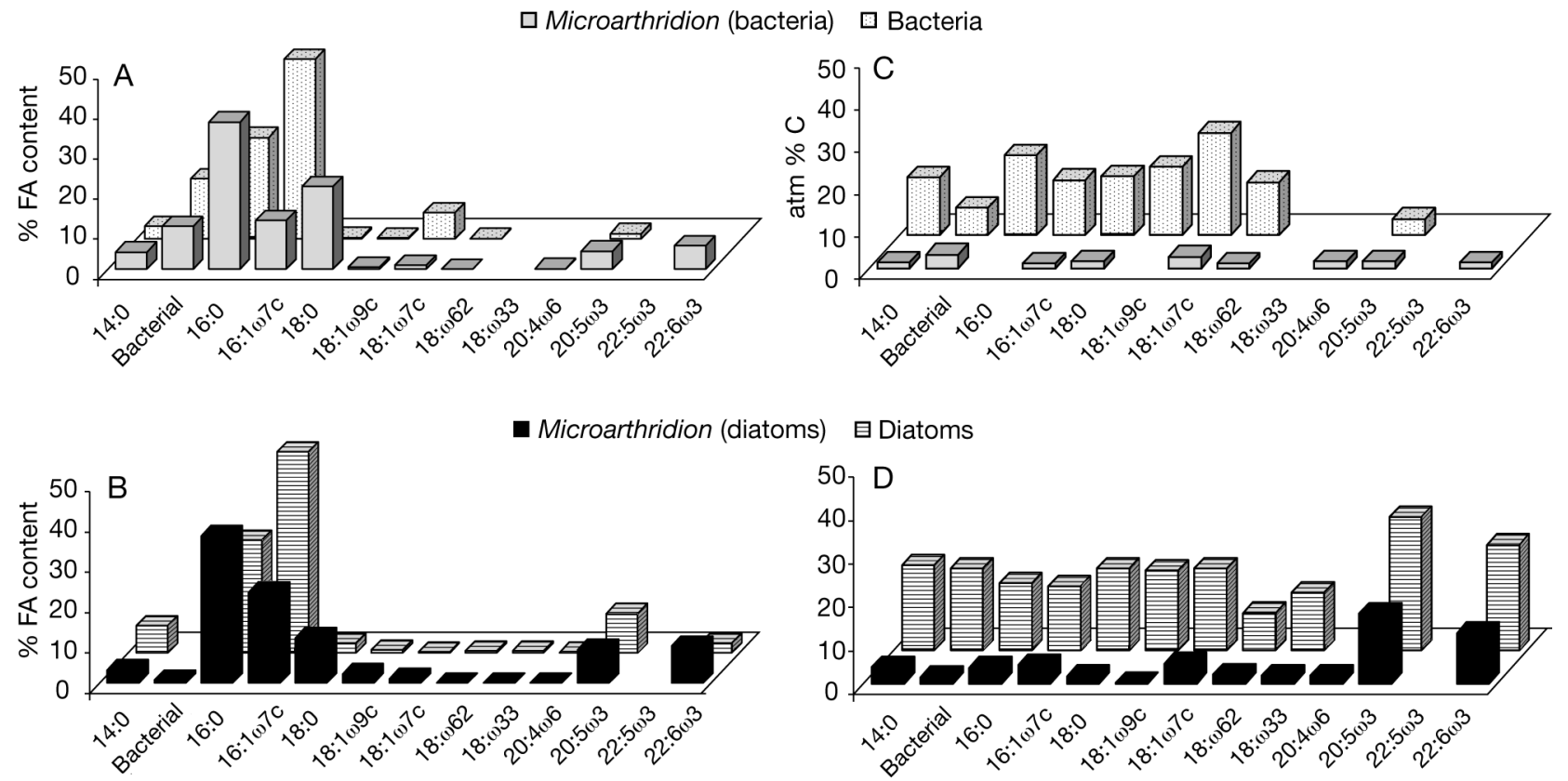

Fig. 1. Relative FA composition (\% FA) of dietary diatoms and bacteria and of Microarthridion littorale after $9 \mathrm{~d}$ of feeding on (A) bacteria or (B) diatoms and $(\mathrm{C}, \mathrm{D})$ the corresponding atomic ${ }^{13} \mathrm{C}$ percentage

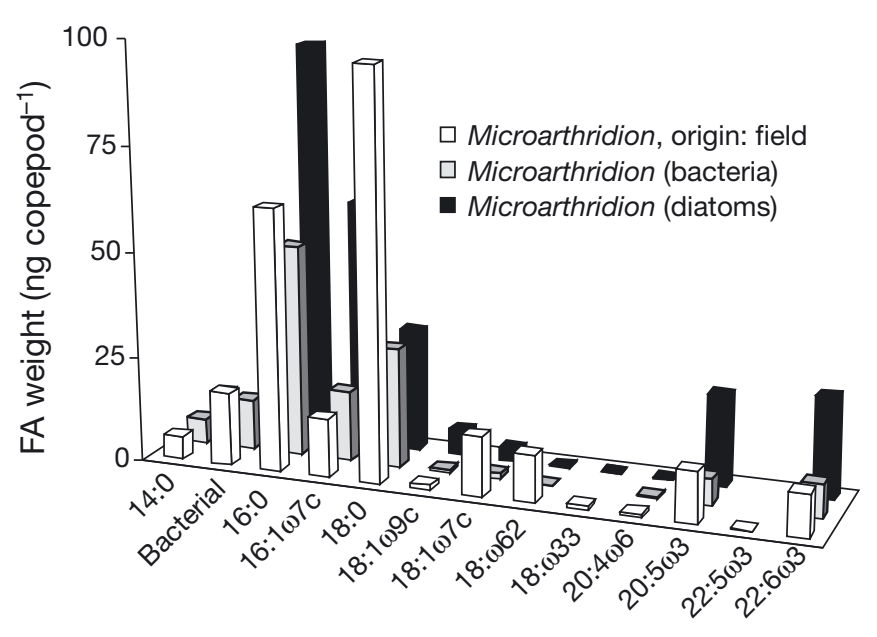

Fig. 2. Absolute FA composition (ng weight copepod $^{-1}$ ) of Microarthridion littorale collected in the field and after $9 \mathrm{~d}$ of feeding on the dietary diatoms or bacteria

was higher $(36.7 \%)$ in the copepods feeding on bacteria than the relative proportion of 16:0 in bacteria $(25.3 \%)$, mainly because of the lower decrease in the absolute content of $\mathrm{C} 16$ relative to other FA (Figs. 1 \& 2). In copepods feeding on diatoms, the increase in the proportion of $16: 0$ from 27.9 to $36.6 \%$ resulted from an increase in the 16:0 absolute content. Due to the high variance of the relative 16:0 content in the copepods after the feeding experiments, this increase was, however, not significant.

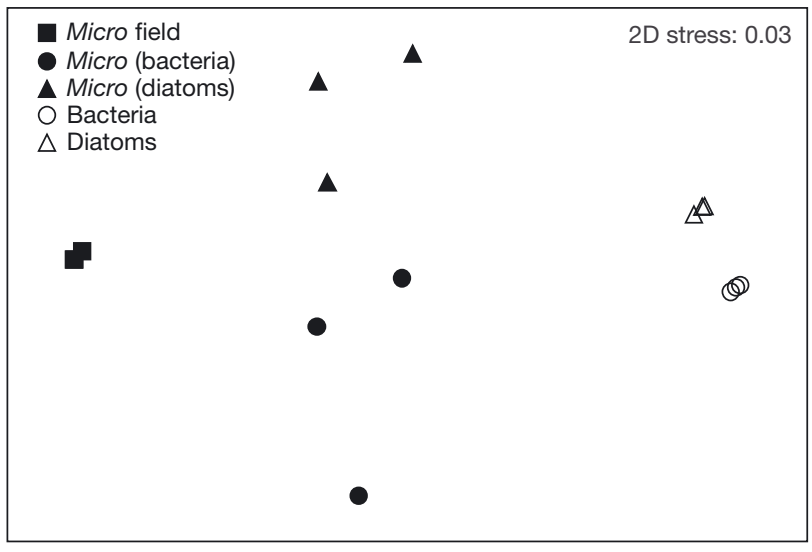

Fig. 3. Non-metric multidimensional scaling (Bray-Curtis similarity) on untransformed, absolute FA concentrations for the various treatments, field samples and food sources (bacteria or diatoms). Micro: Microarthridion littorale

The relative amount of 16:1 107 in copepods grazing on diatoms increased by nearly 5 -fold, and concomitantly, there was a general decrease in 18:0, 18:1 $\omega 7 \mathrm{C}$

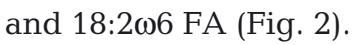

The absolute abundances of LC-PUFA increased in the copepods feeding on diatoms but not in the copepods feeding on bacteria (Fig. 2). In copepods feeding on diatoms, the proportion of EPA nearly doubled from $5.0 \%$ (12.4 $\mathrm{ng} \mathrm{copepod}^{-1}$, field) to $8.7 \%$ (21.9 $\mathrm{ng}$ copepod $^{-1}$, diatom treatment). The same trend was observed for DHA in copepods feeding on diatoms 
(Fig. 2). Conversely, the absolute amount of LC-PUFA in copepods feeding on bacteria for $9 \mathrm{~d}$ decreased relative to field copepods (Fig. 2). The large drop in the absolute amount of EPA and DHA in copepods feeding on bacteria for $9 \mathrm{~d}$ was accompanied by a larger decrease in other FA. On the one hand, the decrease of the absolute concentration of EPA in copepods feeding on bacteria to half of the amount in field copepods (Fig. 2) did not result in any significant change of the relative contribution of EPA to the total FA ( $4.9 \%$ in field copepods, $4.7 \%$ EPA in copepods feeding on bacteria). On the other hand, the absolute decrease in DHA, from $10.2 \mathrm{ng}$ copepod $^{-1}$ (field) to $7.9 \mathrm{ng}$ copepod $^{-1}$ (bacteria treatment) (Fig. 2 ), corresponded to an increase in the relative contribution of DHA to the total FA weight $4.1 \%$ DHA in field copepods vs. $6.1 \%$ DHA in copepods feeding on bacteria) (Fig. 1).

The non-metric multidimensional scaling applied to the FA profiles of copepods and their food sources (Fig. 3) revealed a clear separation among copepods from the field, copepods feeding on either bacteria or diatoms in the laboratory, and diatoms and bacteria applied as copepod food sources (ANOSIM, global R: 0.888, $\mathrm{p}=0.001$; stress 0.03 ). The field samples showed hardly any variance and were plotted together (SIMPER, similarity: $99.6 \%$ ). This high similarity was mainly attributed to FA 18:0 (36.7\%) and 16:0 (23.6\%) (SIMPER). Within the experimental treatments, copepods were separated based on the diet applied (ANOSIM, pairwise comparison of Microarthridion littorale [bacteria] and $M$. littorale [diatoms], $\mathrm{R}=0.556$ ). It is worth noting that after $9 \mathrm{~d}$ of experimental feeding, copepods diverged from their original FA composition (field) toward the composition of the applied food sources (ANOSIM, R $=0.833$ and $\mathrm{R}=1$ for $M$. littorale [bacteria] and $M$. littorale [diatoms], respectively). The food sources (bacteria and diatoms) were also plotted separately from each other (ANOSIM, $R=1$ ). EPA and 16:1 107 were the major contributors to the dissimilarity between both food sources (SIMPER, 17 and $13.6 \%$, respectively).

\section{Origin of carbon in the FA of the copepods}

The mass of carbon incorporated into the copepod FA from the diet was calculated based on the excess atom $\%{ }^{13} \mathrm{C}$ in the grazers and the excess atom $\%{ }^{13} \mathrm{C}$ in the corresponding dietary FA (Fig. 4A,B). The bacterial diet (Fig. 4A) contributed very little carbon weight to the carbon mass of the copepod FA. When feeding on diatoms (Fig. 4B), the carbon of diatom origin largely contributed to the FA carbon in the copepod, reaching $46.8 \%$ of the total carbon in EPA, i.e. $8.1 \mathrm{ng}$ out of $17.3 \mathrm{ng}$ carbon in EPA (Fig. 4B).

The proportion of incorporated dietary carbon into copepod FA followed the relative availability of the FA in the diet (Fig. 4C,D), with the exception of DHA, for copepods feeding on diatoms (Fig. 4D). Copepods feeding on bacteria selectively incorporated more carbon from EPA $(20: 5 \omega 3)$ than from C16 FA that were more abundant in the diet (Fig. 4C). Addition-

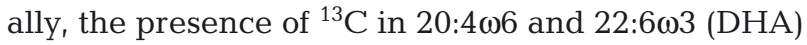
in the copepods feeding on bacteria could not result from a direct incorporation of dietary FA since both 20:4 $\omega 6$ and DHA were absent in the food source. This indicates that these LC-PUFA originated to some extent from ${ }^{13} \mathrm{C}$ labelled SC-FA in the original food source.

The decrease in $\omega 3$ FA carbon in copepods feeding on bacteria was a result of both the decrease in FA already in the body of copepods at the start of the experiment and poor incorporation of bacterial FA (Fig. 5A). 18:3 03 was altogether absent from the body of copepods, and EPA decreased by $>50 \%$ in the body of copepods feeding on bacteria relative to the start of the feeding experiments (Table 1, Fig. 5A). All $\omega 3 \mathrm{FA}$ originating from the field decreased during the feeding experiment (Fig. 5B).

For copepods feeding on diatoms, a decrease in the total carbon of 18:3 $\omega 3$ and increase in both EPA and DHA carbon was registered (Fig. 5A). Considering the proportion of carbon of field origin, both 18:3 $\omega 3$ and EPA carbon decreased (from 0.88 to 0.03 and from 9.82 to $9.28 \mathrm{ng}$ copepod $^{-1}$, respectively) (Table 1), while DHA carbon increased (from 8.23 to $11.49 \mathrm{ng} \mathrm{copepod}^{-1}$ ) (Fig. 5B, Table 1). The decrease in EPA carbon of field origin was counteracted by a high incorporation of diatom carbon in this FA (Fig. 5A; 8.16 ng copepod $^{-1}$ in Table 1). The increase in DHA in copepods feeding on diatoms (Fig. 5A) resulted from both the incorporation of diatom DHA (7.90 ng copepod $\left.{ }^{-1}\right)$ (Table 1) and an increase of the DHA of field origin of $3.26 \mathrm{ng}$ copepod $^{-1}$ (Table 1; difference between 11.49 [lab] and $8.23 \mathrm{ng}$ copepod $^{-1}$ [control]). This increase in field DHA carbon may have resulted from bioconversion from both EPA (0.54 ng cope-

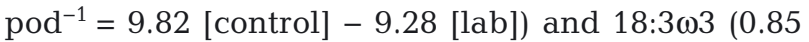
ng copepod ${ }^{-1}=0.88$ [control] -0.03 [lab]) (Table 1). Nevertheless, $1.87 \mathrm{ng}$ copepod $^{-1}$ of DHA carbon of field origin remained unaccounted for. 

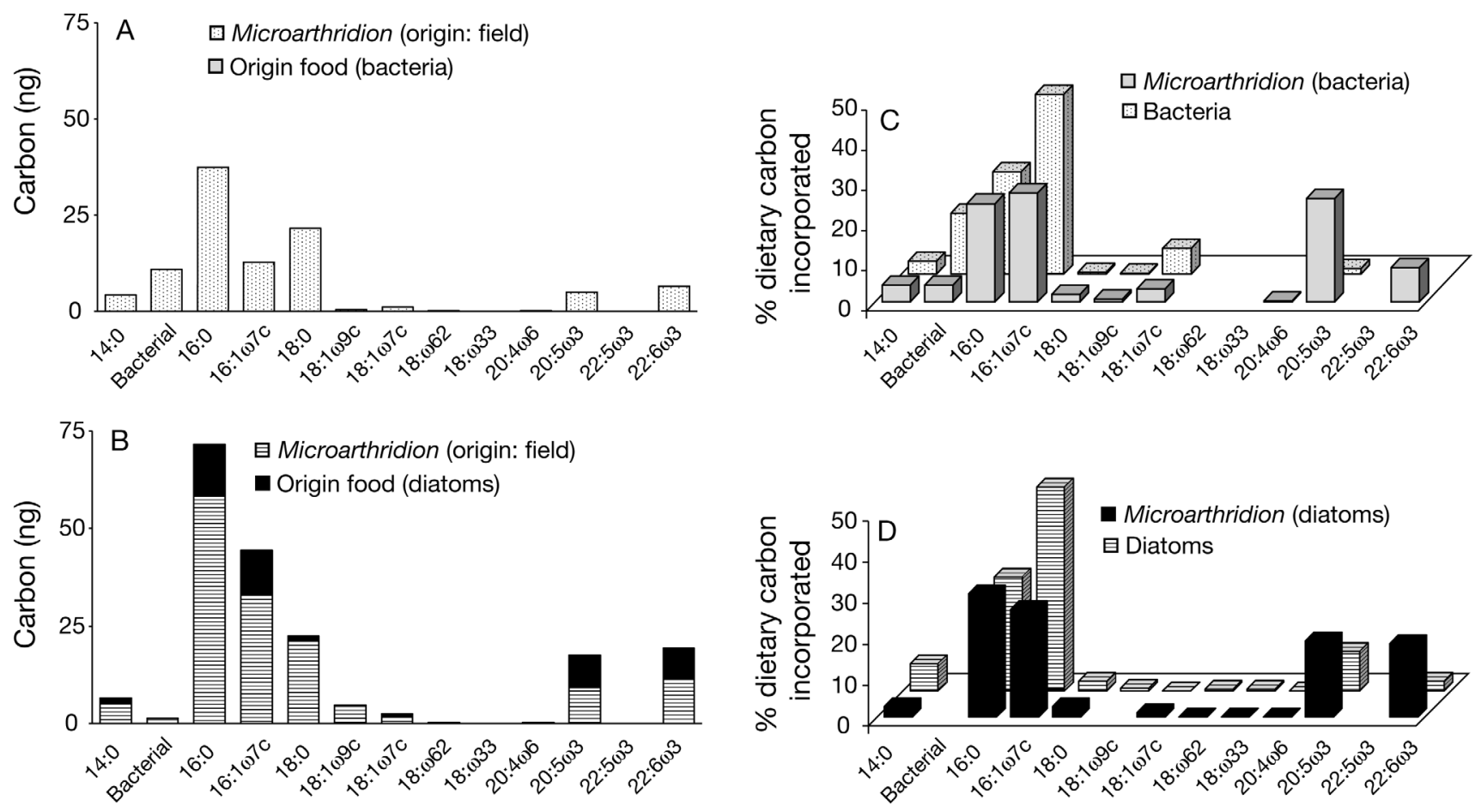

Fig. 4. Total FA carbon variation in copepods feeding on $(A, C)$ bacteria and $(B, D)$ diatoms showing the proportion of carbon of field origin and the proportion of dietary carbon incorporated after $9 \mathrm{~d}$ of feeding on (A) bacteria and (B) diatoms. (C,D) Weight percentage of incorporated dietary carbon in the copepod FA relative to each FA carbon content and FA availability in the diet (C: bacteria, D: diatoms)

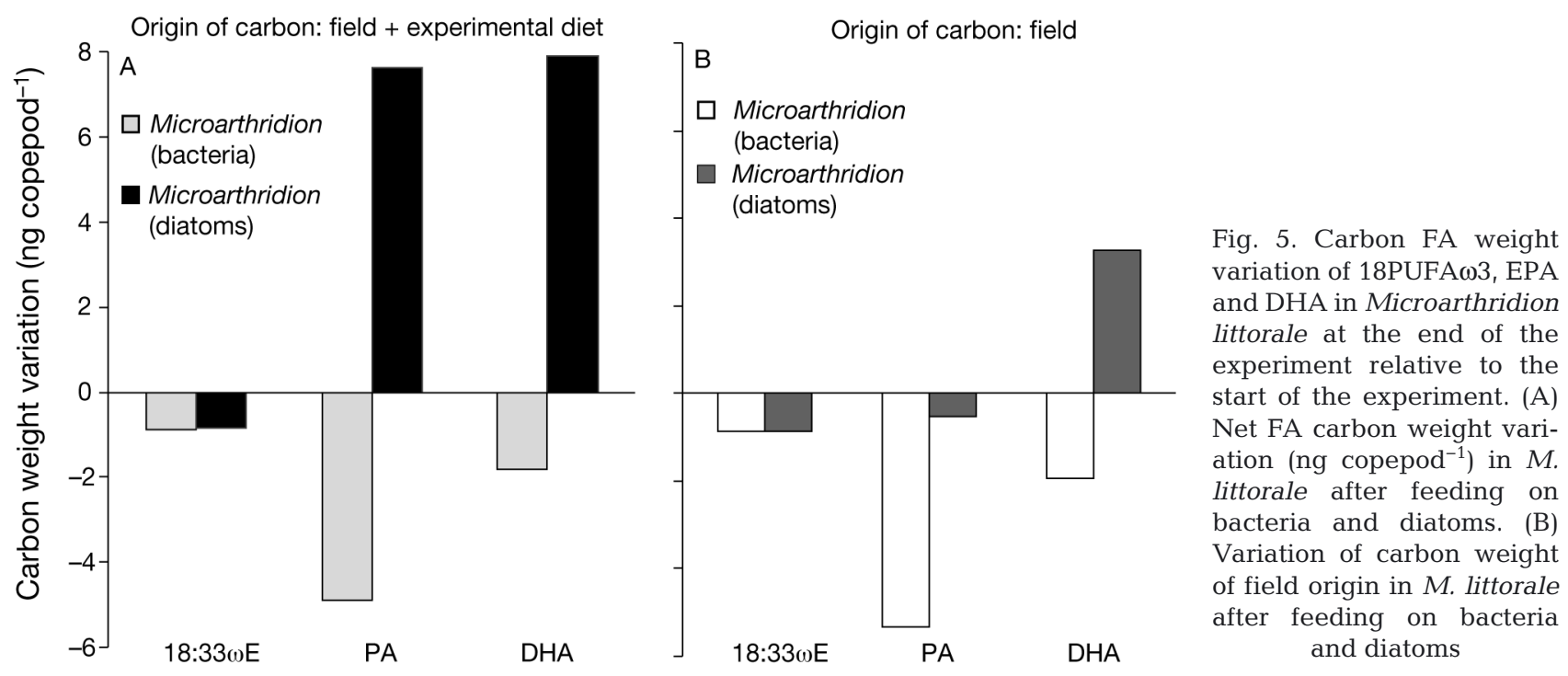

\section{DISCUSSION}

CSIA has been used to distinguish chemosynthetic from photosynthetic food chains in marine systems (MacAvoy et al. 2002, 2003), to assess the contribution of dietary FA to copepod FA and fatty alcohols (Graeve et al. 2005) and to trace carbon flow through marine food webs (Budge et al. 2008). The present study is the first to attempt to assess the selective accumulation of dietary FA and bioconversion of FA by organisms in the lower levels of the benthic food web using CSIA.

The FA composition of the diet is known to reflect on the FA composition of copepods, especially on the 
Table 1. Origin of FA in Microarthridion littorale: relative contribution of fatty acid(s) (FA) from the field vs. dietary FA carbon to the total FA carbon content of $M$. littorale after feeding on bacteria and diatoms. The contribution of FA carbon already in the body of the copepod (Field) and the contribution of FA obtained from the labelled diet (bacterial diet or diatom diet) are given as ng C copepod ${ }^{-1}$. Calculations were based on copepod individual FA carbon content and carbon isotopic signatures for each FA (see 'Materials and methods').

$(-)$ Not detected or trace amounts

\begin{tabular}{|lccccc|}
\hline \multirow{2}{*}{$\begin{array}{c}\text { Origin } \\
\text { of FA }\end{array}$} & \begin{tabular}{c} 
At start of \\
experiment \\
\cline { 2 - 6 }
\end{tabular} & $\begin{array}{c}\text { Feeding } \\
\text { Field }\end{array}$ & Field & $\begin{array}{c}\text { Copepod } \\
\text { Bacterial } \\
\text { diet }\end{array}$ & \multicolumn{2}{c|}{$\begin{array}{c}\text { Feeding on diatoms } \\
\text { Field }\end{array}$} & $\begin{array}{c}\text { Diatom } \\
\text { diet }\end{array}$ \\
\hline $14: 0$ & 4.01 & 4.24 & 0.07 & 5.19 & 1.20 \\
Bacterial & 13.03 & 10.81 & 0.07 & 1.37 & - \\
$16: 0$ & 46.87 & 37.45 & 0.43 & 58.53 & 13.15 \\
$16: 1 \omega 7 \mathrm{c}$ & 10.59 & 12.20 & 0.47 & 33.06 & 11.50 \\
$18: 0$ & 73.67 & 21.52 & 0.03 & 21.14 & 1.20 \\
$18: 1 \omega 9 \mathrm{c}$ & 0.96 & 0.45 & 0.01 & 4.73 & - \\
$18: 1 \omega 7 \mathrm{C}$ & 10.91 & 0.99 & 0.06 & 1.84 & 0.53 \\
$18: 2 \omega 6$ & 8.83 & 0.05 & - & 0.08 & 0.04 \\
$18: 3 \omega 3$ & 0.88 & - & - & 0.03 & 0.01 \\
$20: 4 \omega 6$ & 0.60 & 0.17 & 0.005 & 0.11 & 0.03 \\
$20: 5 \omega 3$ & 9.82 & 4.49 & 0.45 & 9.28 & 8.16 \\
$22: 5 \omega 3$ & 0.09 & - & - & - & - \\
$22: 6 \omega 3$ & 8.23 & 6.28 & 0.15 & 11.49 & 7.90 \\
\hline
\end{tabular}

Based on the feeding experiments, the maintenance of the FA weight content of copepods and high survival rate indicates that Navicula phyllepta is a suitable diet for copepod nutrition. The assimilation of diatom FA in terms of carbon largely mirrored the abundance of FA available in the diet, which resulted in a higher amount of C16 FA, EPA and DHA in the copepod after $9 \mathrm{~d}$ of feeding on the diatoms relative to the copepod composition at the start of the experiment. Nevertheless, there was a preferential accumulation of dietary EPA and DHA relative to C16 FA into the copepod FA. C16 FA and LC-PUFA composed up to 75 and $12 \%$ of diatom FA, respectively, while the copepod incorporated $24.5 \mathrm{ng}$ of C16 FA (56\% of its total FA) and $16 \mathrm{ng}$ of LC-PUFA ( $37 \%$ of its total FA), clearly incorporating a higher proportion of LCPUFA relative to their availability in

apolar lipid fraction. Graeve et al. (1994) demonstrated that diet may induce changes in the FA pattern of neutral lipids in calanoid copepods, and the FA profiles of triacylglycerols (part of the apolar lipid fraction) have been observed to be close to those of the dietary algae (Henderson \& Tocher 1987, Bourdier \& Amblard 1989). This stability of FA during transfer in the food web allied to their great structural diversity with substantial taxonomic specificity has been explored to determine dietary relationships and temporal changes in food sources (Sargent et al. 1987, Fraser et al. 1989, Dalsgaard et al. 2003). The value of FA as diet biomarkers is nevertheless affected by the extent of the transformations that the consumers may perform on ingested FA (Brett \& Müller-Navarra 1997). We analysed the total FA that includes membrane FA, and although the latter are probably under metabolic control and thus weakly influenced by dietary FA (Desvilettes et al. 1997b), yet it was possible to detect FA differences in total FA extracts that could be related to diet FA composition. In the field, copepods likely had access to a variety of food items, since the presence of 18:0 and FA of the $\omega 6$ series point to grazing on protists or smaller animals, while odd-chain length and branched FA are good indicators of feeding on bacteria, and 16:1 107 and EPA may result from feeding on diatoms (Kaneda 1991, Ederington et al. 1995, Desvilettes et al. 1997b, Hirche et al. 2003, Caramujo et al. 2008). the diet. The copepod also incorporated a similar amount of carbon into EPA and DHA (8.1 and $7.9 \mathrm{ng}$ copepod, respectively, each corresponding to $\sim 18 \%$ of its total FA) regardless of the higher availability of EPA in the diatom ( $10 \%$ of EPA vs. $2 \%$ of DHA). DHA may also have originated from bioconversion from dietary EPA since the increase of DHA of field origin in the body of copepods suggests that the copepods must have the ability to obtain DHA through bioconversion from EPA and 18:3 13 already in the body of the copepods at the start of the experiment. Although the FA carbon content of copepods remained constant during feeding, $23 \%$ originated from algal uptake at the end of the $9 \mathrm{~d}$ of feeding. The carbon incorporated must correspond to the metabolic costs of living. It is interesting to note that the carbon replaced by feeding was mainly assimilated into C16 FA and LC-PUFA at the cost of a general depletion of C18 FA, which are nearly absent in the diatom.

The accumulation of LC-PUFA in copepods feeding on diatoms has interesting ecological implications. LC-PUFA were found to play a crucial role in the production and hatching success of the eggs of planktonic copepods (Calanoida) (Jónasdottir et al. 2009). The FA 16:1 107 and 20:5 13 (EPA) are known as principal diatom FA (Kates \& Volcani 1966). Consequently, we can state that a pure diatom diet yields a better survival and a higher LC-PUFA content (pre- 
sent study) and also enhances reproduction (i.e. increased egg production rate and hatching success) (see Jónasdottir et al. 2009) in comparison to the bacterial diet.

Copepods feeding on bacteria decreased both their total carbon content and FA content. This reduction combined with the low survival rate of copepods feeding on bacteria suggests that a pure bacterial diet is unsuitable for the maintenance of copepod growth and survival. Moreover, an even simpler explanation might be that copepods did not (or did inefficiently) feed on the bacteria. This would imply that starvation is the main explanation for the obtained results. It has been shown that bacteria contribute to the diet of harpacticoid copepods (Rieper 1978) and their naupliar stages (Decho \& Fleeger 1988). However, both studies concluded that copepod adults and nauplii ingest bacteria adhering to diatoms (Decho \& Fleeger 1988) or bacteria offered as a paste mixed with sand grains (Rieper 1978).

The ability to convert shorter chain $\omega 3$ polyunsaturated FA into the essential EPA and DHA has been observed in the harpacticoid copepods Tisbe sp. (Norsker \& Støttrup 1994, Nanton \& Castell 1998) and Tigriopus sp. (Watanabe et al. 1978). Different harpacticoid species seem to have different nutritional requirements, and it has been long noted that certain harpacticoid species are not 'able to develop within a normal amount of time living on these bacteria alone' (Rieper 1978). During the $9 \mathrm{~d}$ of feeding on bacteria, the copepods lost $50 \%$ of their FA content, although the loss of DHA was only $22 \%$. This indicates that the copepods must have some specific physiological demand for DHA that requires its conservation. A similar trend was observed for the marine copepods Temora longicornis and Eurytemora sp. (Evjemo et al. 2003), whose DHA/EPA ratio increased during starvation. It was suggested that the preferential retention of DHA at the end of the starvation period was most likely a result of the fact that DHA is primarily located in the phospholipids, which are mostly structural lipids and not as sensitive to starvation as the reserve lipids (i.e. triacylglycerides and wax esters).

The importance of DHA is further emphasised by the fact that the copepod contained labelled DHA that was altogether absent in bacteria. The copepod must have bioconverted DHA from bacterial EPA, attempting to maintain a certain content of EPA and DHA, both of which are essential as major membrane constituents (Albers et al. 1996).

The copepods showed a small incorporation of car-

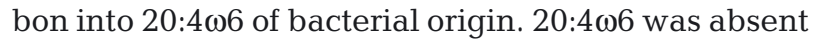

from the bacteria, and 18:2 $\omega 6$ FA were present in trace amounts in the copepod. The copepod must have assimilated the small amount of available $18: 2 \omega 6$ and bioconverted it to $20: 4 \omega 6$, which is a pivotal FA for the physiological functions of copepods (Parrish 2009).

The bacterial assemblage in the present study contained a small amount of EPA $(1.27 \%$ of total FA weight). EPA-producing bacteria are not common in marine environments, yet, out of a total of 5000 strains of bacteria screened, Yazawa et al. (1988) found 88 capable of producing EPA. Until the 1990s, it was considered that bacteria had no PUFA, with the exception of selected cyanobacteria. As noted by Okuyama et al. (2007), such an assumption may have resulted from the fact that the bacterial species whose physiology, biochemistry and molecular biology had been well studied until that time were mesophilic species, such as Escherichia coli, which have no PUFA. Additionally, the culture conditions may also determine the bacterial EPA content that is dependent on $\mathrm{pH}$, temperature and other growth conditions (de Carvalho 2012). Nevertheless, the lack of short chain $\omega 3$ and the presence of a small amount of EPA ( $1.2 \%$ of total FA) in the bacterial assemblage may have determined the unsuitability of the assemblage for the nutrition of Microarthridion littorale regardless of the copepod's ability to bioconvert $\omega 3$ SC-PUFA to $\omega 3$ LC-PUFA.

\section{Transfer of LC-PUFA in the lower marine food web}

As in all ecosystems, most PUFA in aquatic webs originate in the primary producers, essentially the autotrophs. However, recent findings showed that marine protists, namely thraustochytrids, are also a substantial source of PUFA (Raghukumar 2008, Kobayashi et al. 2011). In general, the marine system is characterized by high levels of $\omega 3$-LC-PUFA (EPA and DHA), whereas the freshwater system is charac-

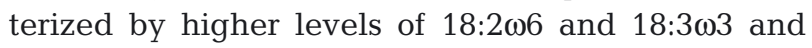
some EPA but low DHA (Brett et al. 2009). Animals

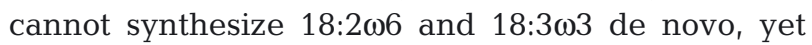
they may convert these FA to LC-PUFA through a series of reactions catalysed by fatty acyl desaturases and PUFA elongases (Iverson 2009). Harpacticoid copepods contain the $\Delta-5, \Delta-6$ desaturase and elongase enzymes necessary for the conversion of the shorter chain linolenic acid $(18: 3 \omega 3)$ to the essential FA EPA (20:5 $\omega 3)$ and DHA (22:6 $\omega 3)$ (Norsker \& Støttrup 1994, Nanton \& Castell 1998, Støttrup 2000). The same enzymes are used in the conversion of linoleic 


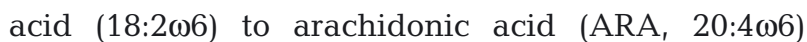
(O'Keefe 2002) and were also found in other invertebrates, e.g. Caenorhabditis elegans (Watts \& Browse 2002).

Although these enzymatic pathways are well documented (Bell \& Tocher 2009), the use of FA from differential food by consumers is far from well known. CSIA allowed us to document the process of bioconversion by harpacticoid copepods feeding on bacteria vs. diatoms. Since copepods possessed isotopically labelled DHA when feeding on a labelled diet lacking DHA, this labelled DHA must be obtained by bioconverting labelled SC-FA in the diet and not from FA already present in the body of the copepod prior to the feeding experiment. Bioconversion must have also been involved in the production of ARA that was measured in the copepod but was missing from the bacterial diet. ARA could have been obtained from $\omega 6$ SC-FA, possibly from 18:2 $\omega 6$, which was present in small amounts in the bacteria. The ability of cyclopoid and harpacticoid copepods to bioconvert FA and survive on poor diets has been suggested by several studies (Norsker \& Støttrup 1994, Nanton \& Castell 1998, 1999, Watanabe et al. 1978).

This ability exhibited by harpacticoids contrasts to that of calanoids, whose DHA content fluctuates dramatically in short periods of time as a result of phytoplankton composition (Davis \& Olla 1992). Conversely, harpacticoid copepods, which typically inhabit detritus-rich environments where food is deficient in essential FA, do possess the ability to actively synthesize these compounds in significant quantities (Nanton \& Castell 1998). In the present study, Microarthridion littorale did exhibit the ability to bioconvert SC-FA to LC-PUFA, although the efficiency of bioconversion is apparently dependent on the FA availability and composition in the food source. When feeding on diatoms, the copepods incorporate 53-fold more dietary DHA in their tissues than when feeding on bacteria. Although the direct assimilation of DHA from diatoms must have taken place, a certain degree of bioconversion of EPA into DHA must have occurred, as suggested by the considerable increase in DHA that originated from the field and that could only be obtained from EPA and 18:3 $\omega 3$ present in the body of copepods before the start of the feeding experiments (see Fig. 5).

\section{Bioconversion: implications}

Although FA can be powerful tracers of carbon flow, food webs, predator-prey interactions and even ecosystem structure and functioning within aquatic ecosystems (Iverson 2009), modifications of FA by bioconversion should be taken into account when using them as biomarkers.

In addition, these findings have important implications for higher trophic levels feeding on copepods (e.g. juvenile fish). The present study shows that primary consumers like harpacticoids are able to improve the quality of the consumed food, mainly in terms of increased DHA content that will become available to the next trophic level.

The application of CSIA allowed the quantification of the FA bioconverted from FA in the labelled diet and measurement of the precise FA biomass on e.g. the DHA yield from bioconversion. We proved that even traces of SC-PUFA can be used by the copepod as precursors and bioconverted to LC-PUFA of the same insaturation type (e.g. $\omega 6$ ). While contrasting FA profiles of food sources and consumers merely indicated the presence or absence of a certain FA, CSIA allowed the identification of the actual origin of FA and especially of LC-PUFA. The present study also quantified the contribution of 2 main food sources, bacteria and diatoms, in marine sediment communities to the FA pool of the consumer. Moreover, it illustrated that any shortage of essential FA was compensated by bioconversion. This could be documented based on a relatively short term experiment (9 d), indicating that consumers quickly respond to potential shortages of FA in their food sources.

Acknowledgements. The first author was a postdoctoral fellow of the Research Foundation-Flanders (FWO-Flanders, Belgium) at the time of the experiment and is now financed by Ghent University (BOF-GOA 01GA1911W). M.J.C. received grant SFRH/BPD/25259/2005 awarded by Fundação para a Ciência e a Tecnologia, Portugal, and her research stay at the UGent was supported by ESF Research Program G.0670.07 and research project G.0313.04 of the Research Foundation-Flanders. The authors thank 3 anonymous reviewers for their constructive remarks that contributed to the improvement of the manuscript.

\section{LITERATURE CITED}

Abdulkadir S, Tsuchiya M (2008) One-step method for quantitative and qualitative analysis of fatty acids in marine animal samples. J Exp Mar Biol Ecol 354:1-8

Albers CS, Kattner G, Hagen W (1996) The compositions of wax esters, triacylglycerols and phospholipids in Arctic and Antarctic copepods: evidence of energetic adaptations. Mar Chem 55:347-358

Bell MV, Tocher DR (2009) Biosynthesis of polyunsaturated fatty acids in aquatic ecosystems: general pathways and new directions. In: Arts MT, Brett MT, Kainz MJ (eds) Lipids in aquatic ecosystems. Springer, Dordrecht, p 211-236 
Bell MV, Dick JR, Anderson TR, Pond DW (2007) Application of liposome and stable isotope tracer techniques to study polyunsaturated fatty acid biosynthesis in marine zooplankton. J Plankton Res 29:417-422

Bourdier G, Amblard C (1989) Lipids in Acanthodiaptomus denticornis during starvation and fed on three different algae. J Plankton Res 11:1201-1212

Brett MT, Goldman CR (1997) Consumer versus resource control in freshwater pelagic food webs. Science 275: 384-386

Brett MT, Müller-Navarra DC (1997) The role of fatty acids in aquatic foodweb processes. Freshw Biol 38:483-499

Brett MT, Müller-Navarra DC, Persson J (2009) Crustacean zooplankton fatty acid composition. In: Arts MT, Brett MT, Kainz MJ (eds) Lipids in aquatic ecosystems. Springer, Dordrecht, p 115-146

Budge SM, Wooller MJ, Springer AM, Iverson SJ, McRoy CP, Divoky GJ (2008) Tracing carbon flow in an arctic marine food web using fatty acid-stable isotope analysis. Oecologia 157:117-129

Buffan-Dubau E, Carman KR (2000) Diel feeding behavior of meiofauna and their relationships with microalgal resources. Limnol Oceanogr 45:381-395

Canuel EA, Cloern JE, Ringelberg DB, Guckert JB, Rau GH (1995) Molecular and isotopic tracers used to examine sources of organic matter and its incorporation into the food webs of San Francisco Bay. Limnol Oceanogr 40: $67-81$

Caramujo MJ, Boschker E, Admiraal W (2008) Fatty acid profiles of algal diet mark the development and fatty acid composition of harpacticoid copepods. Freshw Biol 53: 77-90

> Chandler GT, Fleeger JW (1987) Facilitative and inhibitory interactions among estuarine meiobenthic harpacticoid copepods. Ecology 68:1906-1919

Clarke KR, Gorley RN (2006) PRIMER v6: user manual/ tutorial. PRIMER-E, Plymouth

> Dalsgaard J, St. John M, Kattner G, Müller-Navarra D, Hagen W (2003) Fatty acid trophic markers in the pelagic marine environment. Adv Mar Biol 46:225-340

> Davis MW, Olla BL (1992) Comparison of growth, behavior and lipid concentrations of walleye pollock Theragra chalcogramma larvae fed lipid-enriched, lipid-deficient and field-collected prey. Mar Ecol Prog Ser 90:23-30

de Carvalho CC (2012) Adaptation of Rhodococcus erythropolis cells for growth and bioremediation under extreme conditions. Res Microbiol 163:125-136

De Troch M, Mees J, Wakwabi EO (1998) Diets of abundant fishes from beach seine catches in seagrass beds of a tropical bay (Gazi Bay, Kenya). Belg J Zool 128:135-154

> De Troch M, Steinarsdóttir MB, Chepurnov V, Ólafsson E (2005) Grazing on diatoms by harpacticoid copepods: species-specific density-dependent uptake and microbial gardening. Aquat Microb Ecol 39:135-144

De Troch M, Grego M, Chepurnov VA, Vincx M (2007) Food patch size, food concentration and grazing efficiency of the harpacticoid Paramphiascella fulvofasciata (Crustacea, Copepoda). J Exp Mar Biol Ecol 343:210-216

> De Troch M, Cnudde C, Willems A, Moens T, Vanreusel A (2010) Bacterial colonization on fecal pellets of harpacticoid copepods and on their diatom food. Microb Ecol 60: 581-591

$>$ Decho AW (1986) Water-cover influences on diatom ingestion rates by meiobenthic copepods. Mar Ecol Prog Ser 33:139-146
Decho AW, Fleeger JW (1988) Ontogenetic shifts in the meiobenthic harpacticoid copepod Nitocra lacustris. Mar Biol 97:191-197

Desvilettes CH, Bourdier G, Amblard CH, Barth B (1997a) Use of fatty acids for the assessment of zooplankton grazing on bacteria, protozoans and microalgae. Freshw Biol 38:629-637

Desvilettes CH, Bourdier G, Breton JC (1997b) On the occurrence of a possible bioconversion of linolenic acid into docosahexaenoic acid by the copepod Eucyclops serrulatus fed on microalgae. J Plankton Res 19:273-278

> Drijber RA, Doran JW, Parkhurst MA, Lyon DJ (2000) Changes in microbial community structure with tillage under long-term wheat-fallow management. Soil Biol Biochem 32:1419-1430

Dunstan GA, Volkman JK, Barret SM, Leroi JM, Jeffery SW (1993) Essential polyunsaturated fatty acids from 14 species of diatom (Bacillariophyceae). Phytochemistry 35: $155-161$

> Eder K (1995) Gas chromatographic analysis of fatty acid methyl esters. J Chromatogr B Biomed Appl 671: 113-131

> Ederington MC, McManus GB, Harvey HR (1995) Trophic transfer of fatty acids, sterols, and a triterpenoid alcohol between bacteria, a ciliate, and the copepod Acartia tonsa. Limnol Oceanogr 40:860-867

> El-Sabaawi R, Dower JF, Kainz M, Mazumder A (2009) Characterizing dietary variability and trophic positions of coastal calanoid copepods: insight from stable isotopes and fatty acids. Mar Biol 156:225-237

Evjemo JO, Reitan KI, Olsen Y (2003) Copepods as live food organisms in the rearing of Atlantic halibut (Hippoglossus hippoglossus L.) with special emphasis on nutritional value. Aquaculture 227:191-210

> Fraser AJ, Sargent JR, Gamble JC, Seaton D (1989) Formation and transfer of fatty acids in an enclosed marine food chain comprising phytoplankton, zooplankton and herring (Clupea harengus) larvae. Mar Chem 27:1-18

Graeve M, Kattner G, Hagen W (1994) Diet-induced changes in the fatty acid composition of Arctic herbivorous copepods: experimental evidence of trophic markers. J Exp Mar Biol Ecol 182:97-110

> Graeve M, Albers C, Kattner G (2005) Assimilation and biosynthesis of lipids in Arctic Calanus species based on feeding experiments with a ${ }^{13} \mathrm{C}$ labeled diatom. J Exp Mar Biol Ecol 317:109-125

Guckert JB, Antworth CP, Nichols PD, White DC (1985) Phospholipid, ester-linked fatty acid profiles as reproducible assays for changes in prokaryotic community structure of estuarine sediments. FEMS Microbiol Ecol 31:147-158

Guillard RL (1975) Culture of phytoplankton for feeding marine invertebrates. In: Smith WL, Chandley MH (eds) Culture of marine invertebrate animals. Plenum Press, New York, NY, p 29-60

> Henderson RJ, Tocher DR (1987) The lipid composition and biochemistry of freshwater fish. Prog Lipid Res 26: 281-347

Hicks GRF, Coull BC (1983) The ecology of marine meiobenthic harpacticoid copepods. Oceanogr Mar Biol Annu Rev 21:67-175

Hirche HJ, Fetzer I, Graeve M, Kattner G (2003) Limnocalanus macrurus in the Kara Sea (Arctic Ocean): an opportunistic copepod as evident from distribution and lipid patterns. Polar Biol 26:720-726 
Iverson SJ (2009) Tracing aquatic food webs using fatty acids: from qualitative indicators to quantitative determination. In: Arts MT, Brett MT, Kainz MJ (eds) Lipids in aquatic ecosystems. Springer, Dordrecht, p 281-307

Jónasdóttir SH, Visser AW, Jespersen C (2009) Assessing the role of food quality in the production and hatching of Temora longicornis eggs. Mar Ecol Prog Ser 382:139-150

$>$ Kaneda T (1991) Iso- and anteiso-fatty acids in bacteria: biosynthesis, function, and taxonomic significance. Microbiol Rev 55:288-302

Kates M, Volcani BE (1966) Lipid components of diatoms. Biochim Biophys Acta 116:264-278

Kelly JR, Scheibling RE (2012) Fatty acids as dietary tracers in benthic food webs. Mar Ecol Prog Ser 446:1-22

Kharlamenko VI, Kiyashko SI, Imbs AB, Vyshkvartzev DI (2001) Identification of food sources of invertebrates from the seagrass Zostera marina community using carbon and sulfur stable isotope ratio and fatty acid analyses. Mar Ecol Prog Ser 220:103-117

> Kharlamenko VI, Kiyashko SI, Rodkina SA, Imbs AB (2008) Determination of food sources of marine invertebrates from a subtidal sand community using analyses of fatty acids and stable isotopes. Russ J Mar Biol 34:101-109

Kirsch PE, Iverson SJ, Bowen WD, Kerr SR, Ackman RG (1998) Dietary effects on the fatty acid signature of whole Atlantic cod (Gadus morhua). Can J Fish Aquat Sci 55: 1378-1386

Kiyashko SI, Kharlamenko VI, Imbs AB (1998) Stable isotope ratios and fatty acids as food source markers of depositfeeding invertebrates. Russ J Mar Biol 24:170-174

Kobayashi T, Sakaguchi K, Matsuda T, Abe E and others (2011) Increase of eicosapentaenoic acid in thraustochytrids through thraustochytrid ubiquitin promoterdriven expression of a fatty acid $\Delta 5$ desaturase gene. Appl Environ Microbiol 77:3870-3876

Lee CS, O'Bryen PJ, Marcus NH (2005) Copepods in aquaculture. Blackwell Publishing, Oxford

- MacAvoy SE, Macko SA, Joye SB (2002) Fatty acid carbon isotope signatures in chemosynthetic mussels and tube worms from gulf of Mexico hydrocarbon seep communities. Chem Geol 185:1-8

MacAvoy SE, Macko SA, Carney RS (2003) Links between chemosynthetic production and mobile predators on the Lousiana continental slope: stable carbon isotopes of specific fatty acids. Chem Geol 201:229-237

Matson PA, Hunter MD (1992) The relative contribution of top-down and bottom-up forces in population and community ecology: Special Feature Ecology 73. Ecological Society of America, Washington, DC

$>$ Micheli F (1999) Eutrophication, fisheries, and consumerresource dynamics in marine pelagic ecosystems. Science 285:1396-1398

> Middelburg JJ, Barranguet C, Boschker HTS, Herman PMJ, Moens T, Heip CHR (2000) The fate of intertidal microphytobenthos carbon: an in situ ${ }^{13} \mathrm{C}$-labeling study. Limnol Oceanogr 45:1224-1234

Müller-Navarra DC, Brett MT, Park S, Chandra S, Ballantyne AP, Zorita E, Goldman CR (2004) Unsaturated fatty acid content in seston and tropho-dynamic coupling in lakes. Nature 427:69-72

$>$ Nanton DA, Castell JD (1998) The effects of dietary fatty acids on the fatty acid composition of the harpacticoid copepod, Tisbe sp., for use as a live food for marine fish larvae. Aquaculture 163:251-261

Nanton DA, Castell JD (1999) The effects of temperature and dietary fatty acids on the fatty acid composition of harpacticoid copepods, for use as a live food for marine fish larvae. Aquaculture 175:167-181

Napolitano G (1999) Fatty acids as trophic and chemical markers in freshwater ecosystems. In: Arts MT, Wainman BC (eds) Lipids in freshwater ecosystems. Springer, Dordrecht, p 21-44

Norsker NH, Støttrup JG (1994) The importance of dietary HUFAs for fecundity and HUFA content in the harpacticoid, Tisbe holothuriae Humes. Aquaculture 125: 155-166

> Nyssen F, Brey T, Dauby P, Graeve M (2005) Trophic position of Antarctic amphipods - enhanced analysis by a 2-dimensional biomarker assay. Mar Ecol Prog Ser 300: 135-145

O'Keefe SF (2002) Nomenclature and classification of lipids. In: Akoh CC, Min DB (eds) Food lipids - chemistry, nutrition, and biotechnology, 2nd edn. Marcel Dekker, New York, NY, p 1-40

Okuyama H, Orikasa Y, Nishida T, Watanabe K, Morita N (2007) Bacterial genes responsible for the biosynthesis of eicosapentaenoic and docosahexaenoic acids and their heterologous expression. Appl Environ Microbiol 73: 665-670

> Olsen Y (2011) Resources for fish feed in future mariculture. Aquacult Environ Interact 1:187-200

Pancost RD, Pagani M (2006) Controls on the carbon isotopic compositions of lipids in marine environments. In: Volkman J (ed) The handbook of environmental chemistry, Vol 2. Series: marine organic matter: biomarkers, isotopes and DNA. Springer, Heidelberg, p 209-249

Parrish CC (2009) Essential fatty acids in aquatic food webs. In: Arts MT, Brett MT, Kainz MJ (eds) Lipids in aquatic ecosystems. Springer, Dordrecht, p 309-326

> Raghukumar S (2008) Thraustochytrid marine protists: production of PUFAs and other emerging technologies. Mar Biotechnol (NY) 10:631-640

Rhodes A, Boyd L (2005) Formulated feeds for harpacticoid copepods: implications for population growth and fatty acid composition. In: Lee CS, O'Bryen PJ, Marcus NH (eds) Copepods in aquaculture, 1st edn. Blackwell Publishing, Oxford, p 61-73

> Rieper M (1978) Bacteria as food for marine harpacticoid copepods. Mar Biol 45:337-345

Sargent JR, Henderson RJ (1986) Lipids. In: Corner EDS, O'Hara SCM (eds) The biological chemistry of marine copepods, Vol I. Clarendon Press, Oxford, p 59-164

Sargent JR, Parkes RJ, Mueller-Harvey I, Henderson RJ (1987) Lipid biomarkers in marine ecology. In: Sleigh MA (ed) Microbes in the sea. Ellis Harwood, Chichester, p 119-138

Sogard SM (1984) Utilization of meiofauna as a food source by a grassbed fish, the spotted dragonet Callionymus pauciradiatus. Mar Ecol Prog Ser 17:183-191

> St. John MA, Lund T (1996) Lipid biomarkers: linking the utilization of frontal plankton biomass to enhanced condition of juvenile North Sea cod. Mar Ecol Prog Ser 131: $75-85$

StatSoft (2004) STATISTICA (data analysis software system), version 7. www.statsoft.com

Støttrup JG (2000) The elusive copepods: their production and suitability in marine aquaculture. Aquacult Res 31: 703-711

Tocher D (2008) Fish as a source of omega-3 long-chain polyunsaturated fatty acids (LC-PUFA): sustainability 
and contaminant issues. SciTopics. www.scitopics.com/ Fish_as_a_source_of_omega_3_long_chain_polyunsatu rated_fatty_acids_LC_PUFA_Sustainability_and_contami nant_issues.html (accessed 21 September 2012)

Ustach JF (1982) Algae, bacteria and detritus as food for the harpacticoid copepod, Heteropsyllus pseudonunni Coull and Palmer. J Exp Mar Biol Ecol 64:203-214

- Watanabe T, Arakawa T, Kitajima C, Fukusho K, Fujit S (1978) Nutritional quality of living feed from the viewpoint of essential fatty acids for fish. Bull Jpn Soc Sci Fish

Editorial responsibility: Just Cebrian,

Dauphin Island, Alabama, USA
44:1223-1227

- Watts JL, Browse J (2002) Genetic dissection of polyunsaturated fatty acid synthesis in Caenorhabditis elegans. Proc Natl Acad Sci USA 99:5854-5859

Wilbur HM (1997) Experimental ecology of food webs: complex systems in temporary ponds. Ecology 78: 2279-2302

Yazawa K, Araki K, Okazaki N, Watanabe K and others (1988) Production of eicosapentaenoic acid by marine bacteria. J Biochem 103:5-7

Submitted: February 6, 2012; Accepted: July 3, 2012

Proofs received from author(s): September 21, 2012 